\title{
Oomycetes RXLR Effectors Function as Both Activator and Suppressor of Plant Immunity
}

\author{
Sang-Keun $\mathrm{Oh}^{1}$, Sophien Kamoun ${ }^{2}$ and Doil Choi ${ }^{1 *}$ \\ ${ }^{1}$ Department of Plant Sciences and Plant Genomics \& Breeding Institute, Seoul National University, Seoul 151-742, Korea \\ ${ }^{2}$ The Sainsbury Laboratory, Norwich NR4 7UH, United Kingdom \\ (Received on April 26, 2010; Accepted on May 28, 2010)
}

Plant pathogenic oomycetes, such as Phytophthora spp., are the causal agent of the most devastating plant diseases. During infection, these pathogens accomplish parasitic colonization of plants by modulating host defenses through an array of disease effector proteins. These effectors are classified in two classes based on their target sites in the host plant. Apoplastic effectors are secreted into the plant extracellular space, and cytoplasmic effectors are translocated inside the plant cell, through the haustoria that enter inside living host cell. Recent characterization of some oomycete Avr genes showed that they encode effector protein with general modular structure including $\mathbf{N}$-terminal conserved RXLR-DEER motif. More detailed evidences suggest that these AVR effectors are secreted by the pathogenic oomycetes and then translocated into the host plant cell during infection. Recent findings indicated that one of the $P$. infestans effector, Avrblb2, specifically induces hypersensitive response (HR) in the presence of Solanum bulbocastanum late blight resistance genes Rpi-blb2. On the other hand, another secreted RXLR protein PexRD8 originated from $P$. infestans suppressed the HCD triggered by the elicitin INF1. In this review, we described recent progress in characterized RXLR effectors in Phytophthora spp. and their dual functions as modulators of host plant immunity.

Keywords : hypersensitive response, Phytophthora, RXLR effector

Plant pathogenic oomycetes: Phytophthora life cycle and infection process

Oomycetes, such as members of the genus Phytophthora, downy mildews and Pythium, are a unique group of fungallike plant pathogens that cause the most destructive diseases on solanaceous crops, ornamental and other plants (Kamoun and Smart, 2005; Lamour and Kamoun, 2009).

\footnotetext{
*Corresponding author.

Phone) +82-2-880-4568, FAX) +82-2-873-2056

E-mail)doil@snu.ac.kr
}

Among them, Phytophthora cause one of the most destructive plant diseases in the world. These pathogens are very difficult to control because they are unaffected by the management of fungicides (reviewd by Fry, 2008; Hausbeck and Lamour, 2004; Kamoun and Smart, 2005). The economically important Phytophthora pathogens are Phytophthora infestans on potato and tomato (causes late blight; the cause of the Irish potato famine in 1846), $P$. sojae on soybean (causes root and stem rot), P. ramorum on oak (causes the sudden oak death), $P$. capsici on pepper and cucumber (causes Phytophthora blight), and P. palmivora on cocoa etc (cause black pod) (Erwin and Riberiro, 1996; Fry, 2008; Hausbeck and Lamour, 2004; Kamoun and Smart, 2005; Rizzo et al., 2005; Schmitthennner, 1985). Other economically important oomycete pathogens are the downy mildews, cause by Plasmopara viticola on grapevines and Peronospora species (the agent of downy mildew on several crops), which are heterogeneous and the obligate parasites (Hewitt and Pearson, 1998). H. arabidopsis, a natural pathogen of Arabidopsis thaliana, figures prominently in research on disease resistance in Arabidopsis (Allen et al., 2004; Slusarenko and Schlaich, 2003). Altogether, oomycetes cause several billion dollars of damages on crop and ornamental plants annually. The use of fungicides targeted against pathogenic oomycetes can provide some level of disease control. However, the development of crops that possess durable genetic resistance, whereby classical breeding or by genetic engineering, provides the best prospect for effective, economical and environmental sound control of oomycetes disease (Kamoun et al., 1999; Kamoun and Smart, 2005).

Oomycetes, Phytophthora and downy mildews, establish intimate associations with host plants and typically require living host cells to complete their life cycle and infection process known as biotrophy (O'Connell and Panstruga, 2006, Panstruga, 2003). P. infestans establishes a two-step infection style typical of hemibiotrophs. First step, $P$. infestans requires living host cells for an early infection process that is followed by extensive necrosis of plant tissue resulting in colonization and sporulation on the leaf surface (Kamoun and Smart, 2005). Second step, infected 
host cell necrotizes and the mycelium develops sporangiophores that emerge through the natural opening (stomata) to produce numerous sporangia (asexual spores), which release zoospores under cool and $>90 \%$ relative humidity conditions for pathogen dispersal (Judelson and Blanco, 2005; Kamoun and Smart, 2005). For P. infestans to successfully infect and colonize its host, a series of pathogenic process are necessary (Kamoun and Smart, 2005).

\section{The RXLR motifs is required for translocation but not for effector activity in plant cells}

During infection, oomycetes accomplish parasitic colonization of plants by modulating host defenses through an array of disease effector protein. Oomycetes RXLR proteins, like bacterial effectors of the type III secretion system (TTSS), are modulator protein organized into two main functional domains (Kamoun, 2006). One is characterized by a highly conserved sequence motif at their N-terminus that is the signal peptide and RXLR region, functions in secretion and translocation into plant cell. Other is encoded by the C-terminal region that follows the effector activity (Fig. 1). However, the RXLR motif is not required for effector activity when the deleted RXLR motif is expressed into host cells (Bos et al., 2006; Oh et al., 2009). In fact, deletion analysis of AVR $3 \mathrm{a}^{\mathrm{KI}}$ and Avrblb2 revealed that the C-terminal 75 amino acids or 34 aa, which excludes the RXLR region was sufficient for avirulence function when expressed directly inside plant cell with cognate $\mathrm{R}$ protein (Bos et al., 2006; 2006; Oh et al., 2009).

However, many questions still remained to be elucidated that how does the N-terminal RXLR motif functions in translocation of effectors to inside of host cell. What is the transport machinery of oomycete RXLR effectors? Possibly, transport machinery of RXLR effectors into host cells could be encoded by the oomycetes, the host or/and oomycetes (Birth et al., 2008; Morgan and Kamoun, 2007; Govers and Bouwmeester, 2008; Tyler, 2009). Interestingly, the oomycetes RXLR motif is a similar sequence, like the 'RXLX(E/Q)' motif, in effectors of the malaria parasite Plasmodium falciparum that invades human erythrocytes (Bhattacharjee et al., 2006). So, is similar machinery used to deliver oomycete and Plasmodium effectors? The answer is "YES". A few reports demonstrated that the $\mathrm{RXLX}(\mathrm{E} / \mathrm{Q})$ motifs is required for translocation of proteins from the parasites Plasmodium into the cytoplasm of host cells, and is similar in sequence, position and function to the oomycete RXLR motif (Bhattacharjee et al., 2006; Govers and Bouwmeester, 2008; Grouffaud et al., 2008; Tyler, 2009). Dou et al. (2008b) examined that the RXLR and dEER motifs, in $P$. sojae Avr1b effector, can be replaced by the closely related

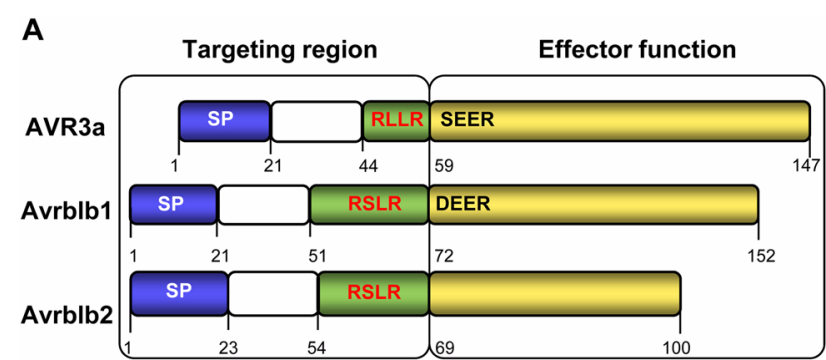

B

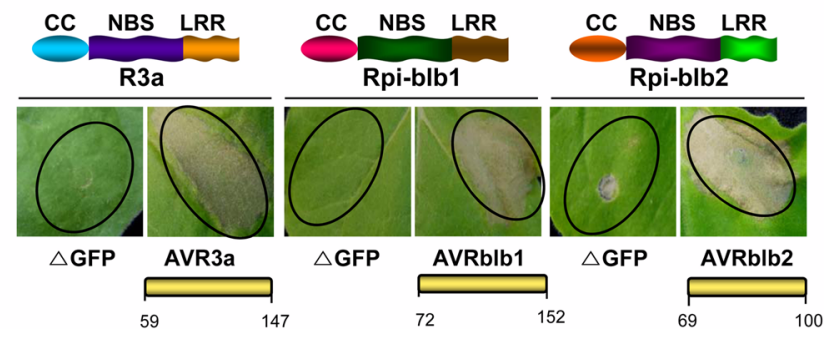

Fig. 1. Domain organization of oomycetes cytoplasmic RXLR effectors and their cognate resistance genes. (A) Schematic drawings of the oomycetes cytoplasmic RXLR effectors AVR3a (Bos et al., 2006), Avrblb1 (IPIO1)(Vleeshouwers et al., 2008), and Avrblb2 (Oh et al., 2009) of Phytophthora infestans. The numbers under the sequences indicate amino acid positions. The boxes distinguish the regions of the effector proteins that are involved in secretion and targeting from those involved in effector activity. (B) Schematic drawings NBS-LRR plant R proteins R3a (Huang et al., 2005), Rpi-blb1 (Song et al., 2003), and Rpi-blb2 (van der Vossen et al., 2005) of potato. After agroinfiltration with mixed three Avr genes and their cognate $\mathrm{R}$ genes, HR cell death was observed starting at 4 DPI in $N$. benthamiana.

erythrocyte-host targeting domains found in effector proteins of Plasmodium, causes malaria in humans. Also, they demonstrated that RXLR and dEER sequences are both necessary and sufficient to deliver the protein into plant cells. Especially, furthermore, they demonstrated that these motifs function in the absence of the pathogen. Thus, it suggested that pathogen-encoded machinery is not required for effector protein entry into plant cells (Dou et al., 2008b). On the other hand, Whisson et al. (2007) demonstrated that the RXLR motif of $P$. infestans AVR3a is required for targeting these oomycetes effectors into host plant cells. Furthermore, an AVR3a fluorescent fusion protein was specifically secreted from haustoria and is translocated into the host plant cell in an RXLR-dEER dependent manner (Fig. 2). However, mutated RXLR to AAAA-motif fusion protein translocated in the intercellular spaces (Whisson et al., 2007). In conclusion, it was evidence that the RXLR motif of P. sojae Avr1b and P. infestans AVR3a are needed to confer avirulence on resistant soybean and potato plants when expressed in the pathogen as a host-targeting domain (Dou et al., 2008b; Whisson et al., 2007). 


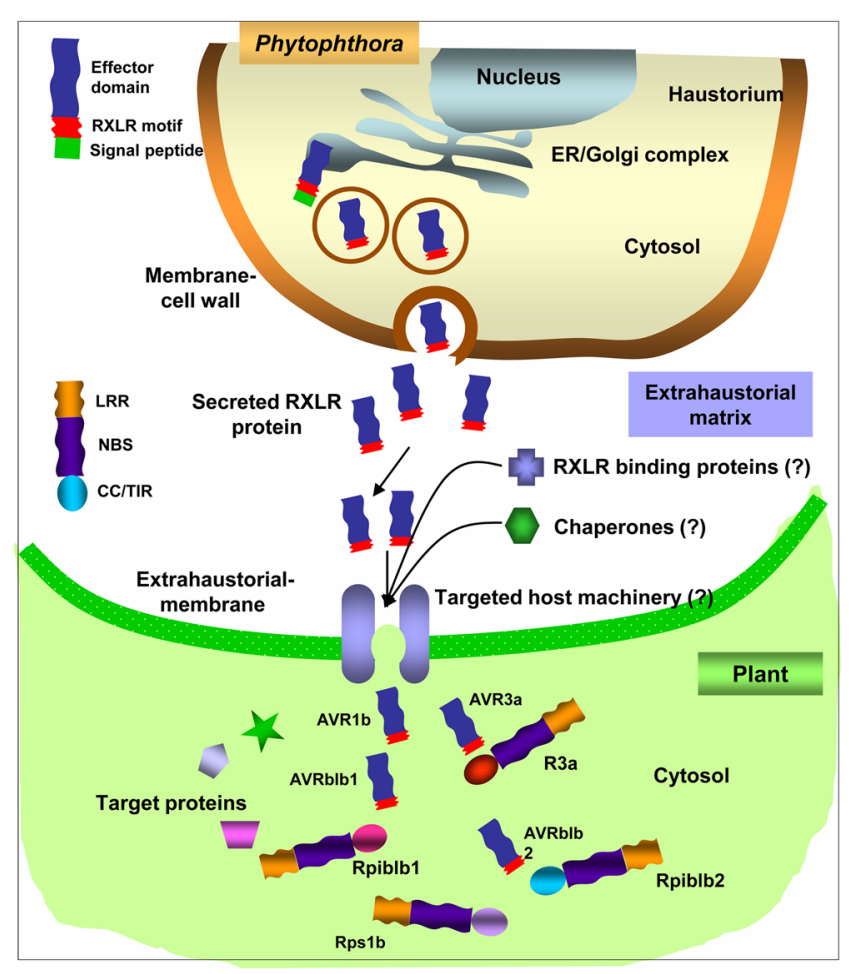

Fig. 2. Plant pathogenic oomycetes effector proteins translocated different sites in host plant cell. Schematic view of RXLR effector secretion by Phytophthora haustoria. Apoplastic effectors (not drawing) are secreted into the extracellular space. Cytoplasmic effectors, such as AVR3a (Bos et al., 2006), Avrblb1 (IPIO1)(Vleeshouwers et al., 2008), Avrblb2 (Oh et al., 2009), and Avrb1 (Dou et al., 2008b) translocated inside host cells, thereby crossing two membranes, one from Phytophthora and another from the host. This mechanism of host translocation remains unclear, but may include Phytophthora-encoded translocator protein. (Modified from Morgan and Kamoun, 2007).

The RXLR effectors are secreted outside the oomycete cell through the general secretory system using endoplasmic reticulum (ER) type signal peptides (SP). And then, the secreted RXLR effectors are transported across a plantderived membrane, probably the oomycete haustorial membrane, though the RXLR leader domain (Fig. 2, reviewed by Morgan and Kamoun, 2007). Also, they proposed that translocation of RXLR effectors in plant involves at least a RXLR binding protein, chaperone(s), and a translocon, which could be of either oomycetes or plant origin. The chaperones are important for folding state maintaining of the transported effectors when transit through the translocon. This model provides a useful hypothesis, and would shed light on the translocation process of RXLR effectors (Fig. 2, Morgan and Kamoun, 2007).

\section{Oomycetes RXLR effector and plant $R$ gene interac- tion in Planta}

To date, $P$. infestans delivers effectors to distinct sites of the host cell where they interact with plant targets to reprogram host defense and promote susceptibility (Birch et al., 2006; 2008; 2009; Morgan and Kamoun 2007; Tyler, 2009). Effectors of the first class are secretes into the plant intracellular space (apoplastic effectors, Kamoun, 2006; 2007), whereas class two effectors are translocated inside the plant cell where they targeted to distinct subcellular compartments (cytoplasmic effectors; Kamoun, 2006). One class of cytoplasmic effectors belongs to the RXLR family which contains a highly conserved motif at their N-terminal region that is similar to host-targeting signal. This signal is required for translocation of proteins into the cytoplasm of host cells (Fig. 2, reviewed by Birch et al., 2009; Kamoun, 2007; Morgan and Kamoun 2007). The other hand, the effector activity is encoded by the C-terminal region that follows the RXLR domain (Fig. 1, Bos et al., 2006; Dou et al., 2008a; Kamoun, 2006; Oh et al., 2009: Vleeshouwers et al., 2008). A comprehensive knowledge of the structure and function of these various classes of effectors and the perturbations they cause in plants is essential for understanding the molecular basis of the late blight disease (Kamoun, 2006; 2007).

Although oomycetes RXLR effectors are thought to function primarily in virulence, they can also function in innate immunity in plant varieties that carry cognate disease $\mathrm{R}$ proteins (reviewed by Kamoun, 2006). Recent findings suggested that oomycete RXLR effectors are specifically induce hypersensitive response (HR) in the presence of the resistance $(R)$ genes in plant varieties (Allen et al., 2004; Armstrong et al., 2005; Bos et al., 2006; Dou et al., 2008a; 2008b; Oh et al., 2009; van Poppel et al., 2009; Vleeshouwers et al., 2008). These effectors are expected to have an avirulence (Avr) activity, thereby activating directly or indirectly HR cell death and associated disease resistance responses mediated by specific R proteins (Fig. 1 and 2, Allen et al., 2004; Armstrong et al., 2005; Bos et al., 2006; Dou et al., 2008b; Oh et al., 2009; van Poppel et al., 2009; Vleeshouwers et al., 2008). The "gene-for-gene hypothesis" was introduced by Flor in the 1940s, a well-characterized perception mechanism, is based on plant $R$ products confer recognition of cognate pathogen Avr proteins, and a number of $A v r-R$ gene combinations have since been characterized (Dangl and Jones, 2001). Recent reports demonstrated that secreted effectors from Phytophthora that contain a RXLR motif are translocated inside plant cells where they target distinct subcellular compartments (Bhattacharjee et al., 2006; Grouffaud et al., 2008). Effector 
activity is thought to be recognized by intracellular Rprotein in plant cells (cytoplasmic proteins), culminating in defense signaling and resistance to these pathogens (Kamoun 2006; 2007). These proteins have a nucleotide biding site (NBS) and leucine-rich repeats (LRR) and are called NBSLRR proteins that are located in plant cytoplasm (Jones and Dangl, 2006).

\section{Some effectors suppress plant immunity and elicitor- induced hypersensitive response}

The functions by which RXLR effectors promote virulence are currently under intense study. To date, the virulence activities of oomycete RXLR effectors remain largely unknown, but some cases have been shown to suppress plant immunity such as PAMP (pathogen-associated molecular pattern)-triggered immunity. Recently, Bos et al. (2006) demonstrated that expression of AVR3a could suppress the HR cell death of $N$. benthamiana triggered by recognition of the oomycete PAMP, elicitin (Fig. 3, socalled INF1, a sterol carrier protein secreted by all Phyto-

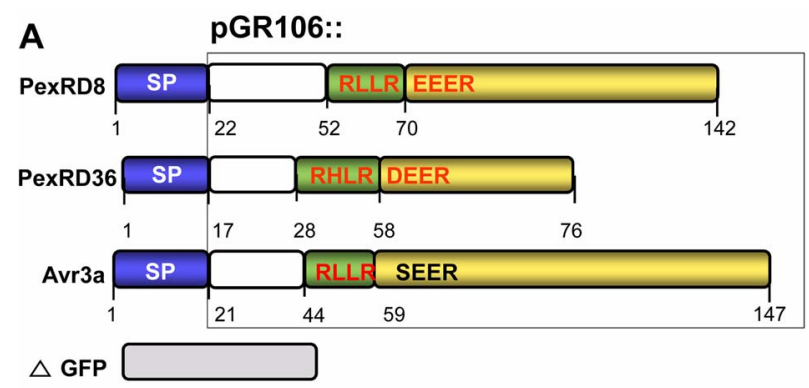

B

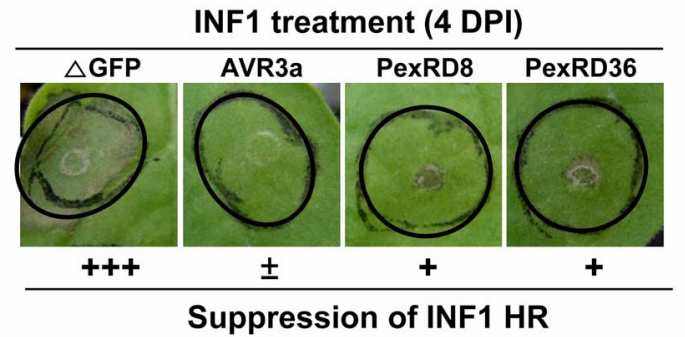

Fig. 3. Two RXLR effectors suppress the HR induce by $P$. infestans INF1 elicitin. (A) Schematic drawings of the oomycetes cytoplasmic RXLR effectors RD8 and RD36 (Oh et al., 2009) of Phytophthora infestans. (B) Agro-infiltration sites in N. benthamiana leaves expressing either PexRD8 or PexRD36 were challenged with $A$. tumefaciens expressing the INF1 elicitin. The INF1induced cell death was scored at 4 DPI. Two independent pGR106-derived clones of PexRD8 and PexRD36 were used. $A$. tumefaciens strain carrying pGR106-GFP was used as a negative control, and pGR106-AVR3a (AVR3a) was used as a positive control. HR cell death index with plus and minus signs indicate the presence and absence of suppression of INF1-induced cell death, respectively. phthora spp, Vleeshouwers et al., 2006). Overexpression of the $P$. sojae RXLR effector Avrlb confers increased pathogen virulence on compatible soybean plants (Dou et al, 2008a), and could suppress the mouse pro-apoptotic protein BAX-triggered PCD (programmed cell death) in $N$. benthamiana (Dou et al., 2008a). BAX is a key regulator of PCD in animals (Borner, 2003). More recently, Oh et al. found that some Phytophthora RXLR effectors could partially suppress the BAX-induced PCD in N. benthamiana (unpublished data). Likewise, some bacterial effectors can suppress BAX-triggered plant PCD (Abramovitch et al., 2003; Jamir et al., 2004). So, these results suggest that the RXLR effectors contribute to oomycetes virulence by suppressing defensive PCD in host plants, which is presumably important during the early biotrophic stage of infection by hemibiotrophic pathogenic oomycetes (reviewed by Tyler, 2009). Additionally, H. arabidopsis ATR13 also could suppress callose deposition, production of reactive oxygene species, and PAMP-triggered (by Psuedomonas syrigae pv. syringae) defense responses in Arabidopsis plants (Jones and Dangl, 2006; Nurnberger et al., 2004), suggesting that RXLR effectors targets basal defenses against various pathogens (Sohn et al., 2007). In addition, Oh et al. (2009) reported that $P$. infestans PexRD8 and PexRD36 could partially suppress HR cell death induced by INF1elicitin (Fig. 3). These observations suggested that oomycete RXLR effectors may have acquired a variety of mechanisms of immune suppression.

\section{Conclusion}

Over the past decade, more than a dozen late blight $R$ genes were introgressed into potato cultivar from the wild species Solanum demissum, and $S$. bulbocastanum using classical breeding technique (Ballvora et al., 2002; Fry, 2008). Some of $R$ genes, $R 1, R 3 a, R B$ (Rpi-blb1) and Rpiblb2, cloned from wild potato cultivar (Ballvora et al., 2002; Huang et al., 2005; Song et al., 2003; van der Vossen et al., 2003; 2005). The biology of RXLR effectors is poorly understood but several informative papers have been published recently (Table 1). However, little is known about the corresponding Avr genes from this pathogen so far (Allen et al., 2004; Armstrong et al., 2005; Bos et al., 2006; Dou et al., 2008a; 2008b; Oh et al., 2009; van Poppel et al., 2009; Vleeshouwers et al., 2008). Five sequences of oomycetes genomes were completed or undergoing completion, much information represent a useful opportunity to study the structure-function of RXLR effector as Avr protein in oomycetes-plants $\mathrm{R}$ protein interaction. Additionally, comparative transcriptomics and genomics of oomycetes provided tremendous data to our understanding of effector genes regulation, genome organization, and evolution 
Table 1. Avirulence RXLR proteins identified in oomycetes of plant pathogen and their corresponding resistance gene.

\begin{tabular}{|c|c|c|c|c|c|c|c|c|}
\hline $\begin{array}{c}\text { RXLR } \\
\text { (AVR) } \\
\text { Effector }\end{array}$ & $\begin{array}{l}\text { Pathogen } \\
\text { species }^{\mathrm{a}}\end{array}$ & $\begin{array}{l}\text { Host } \\
\text { plant }\end{array}$ & $\begin{array}{l}\text { Subcellular } \\
\text { localization }\end{array}$ & $\begin{array}{l}\text { Size } \\
\text { (aa) }\end{array}$ & $\begin{array}{c}\text { Signal } \\
\text { Peptide } \\
\text { \& length }\end{array}$ & $\begin{array}{l}\text { RXLR and } \\
\text { dEER motif }\end{array}$ & $\begin{array}{l}\text { Corresponding } \\
\text { R gene class }{ }^{\mathrm{c}}\end{array}$ & References \\
\hline Avr1b & P. sojae & Soybean & Cytoplasmic & 138 & $\begin{array}{l}\text { Yes } \\
21 \text { aa }\end{array}$ & $\begin{array}{l}\text { RFLR- } \\
\text { EEDDAGER }\end{array}$ & $\begin{array}{l}\text { Rps1b } \\
\text { Unkwon }\end{array}$ & $\begin{array}{l}\text { Shan et al. (2004); } \\
\text { Dou et al. (2008b) }\end{array}$ \\
\hline Avr3a & P. infestans & Potato & Cytoplasmic & 147 & $\begin{array}{c}\text { Yes } \\
21 \text { aa }\end{array}$ & $\begin{array}{l}\text { RLLR- } \\
\text { EENEETSEER }\end{array}$ & $\begin{array}{l}\text { R3a } \\
\text { CC-NBS-LRR }\end{array}$ & $\begin{array}{l}\text { Armstrong et al. (2005); } \\
\text { Bos et al. (2006) }\end{array}$ \\
\hline Avrblb1 & P. infestans & Potato & Cytoplasmic & 152 & $\begin{array}{l}\text { Yes } \\
21 \text { aa }\end{array}$ & RSLR-DEER & $\begin{array}{l}\text { Rpi-blb1 } \\
\text { CC-NBS-LRR }\end{array}$ & Vleeshouwers et al. (2008) \\
\hline Avrblb2 & P. infestans & Potato & Cytoplasmic & 100 & $\begin{array}{c}\text { Yes } \\
23 \text { aa }\end{array}$ & RSLR & $\begin{array}{l}\text { Rpi-blb2 } \\
\text { CC-NBS-LRR }\end{array}$ & Oh et al. (2009) \\
\hline PiAvr4 & P. infestans & Potato & Cytoplasmic & 287 & $\begin{array}{c}\text { Yes } \\
24 \text { aa }\end{array}$ & $\begin{array}{l}\text { RFLR- } \\
\text { DEKNEER }\end{array}$ & $\begin{array}{l}\text { R4 } \\
\text { Unknown }\end{array}$ & Poppel et al. $(2008,2009)$ \\
\hline ATR13 & H. parasitica & Arabidopsis & Cytoplasmic & 187 & $\begin{array}{l}\text { Yes } \\
18 \text { aa }\end{array}$ & RQLR & $\begin{array}{l}\text { RPP13 } \\
\text { CC-NBS-LRR }\end{array}$ & Allen et al. (2004) \\
\hline ATR1 & H. parasitica & Arabidopsis & Cytoplasmic & $311-324$ & $\begin{array}{l}\text { Yes } \\
15 \text { aa }\end{array}$ & RALR-DDDEER & $\begin{array}{l}\text { RPP1 } \\
\text { TIR-NBS-LRR }\end{array}$ & Rehmany et al. (2005) \\
\hline Avrla & P. sojae & Soybean & Cytoplasmic & 121 & $\begin{array}{c}\text { Yes } \\
?\end{array}$ & RXLR & $\begin{array}{l}\text { Rps1a } \\
\text { Unknown }\end{array}$ & Qutob et al. (2009) \\
\hline PiAVR2 & P. infestans & Potato & Cytoplasmic & - & - & - & $\begin{array}{l}\text { R2 } \\
\text { CC-NBS-LRR }\end{array}$ & Lokossou et al. (2009) \\
\hline
\end{tabular}

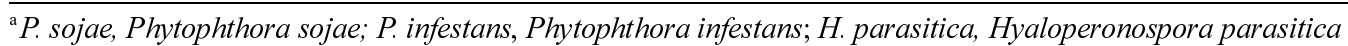

${ }^{\mathrm{b}}$ Based on SignalP v2.0-NN (http;//www.cbs dtu.dk/servies/SignalP-2.0)

${ }^{c}$ Domain structures of the corresponding resistance gene products are indicated as follows : CC, Coiled-Coil; TIR, Toll-interleukin 1 receptor; NBS, Nucleotide Binding Site; LRR, Leucine-rich repeat.

(Haas and Kamoun et al., 2009: Jiang et al., 2008; Tyler et al., 2006; Win et al., 2007). In this review, we described the recent findings on a diverse function of the RXLR proteins of oomycetes cytoplasmic effectors for basic understanding of plant-oomycetes interactions.

\section{Acknowledgements}

This work was financially supported by grants from Crop Functional Genomic Center, the 21st Century Frontier Research Programs funded by Ministry of Education and Science of the Korean Government to DC.

\section{References}

Abramovitch, R. B., Kim, Y.-J., Chen, S., Dickman, M. B. and Martin, G. B. (2003). Pseudomonas type III effector AvrPtoB induces plant disease susceptibility by inhibition of host programmend cell death. EMBOJ. 22:60-69.

Allen, R. L., Bittner-Eddy, P. D., Grenville-Briggs, L. J., Meitz, J. C., Rehmany, A. P., Rose, L. E. and Beynon, L. L. (2004). Host-parasite co-evolutionary conflict between Arabidopsis and downy mildew. Science 306:1957-1960.

Armstrong, M. R., Whisson, S. C., Pritchar, L., Bos, J. I. B., Venter, E., Avrova, A. O., Rehmany, A. P., Böhme, U., Brooks, K., Cherevach, I., Hamlin, N., White, B., Fraser, A., Lord, A.,
Quail, M. A., Churcher, C., Hall, N., Berriman, M., Huang, S., Kamoun, S., Beynon, J. L. and Birch, P. R. J. (2005). An ancestral oomycete locus contains late blight avirulence gene $A v r 3 a$, encoding a protein that is recognized in the host cytoplasm. Proceedings of the National Academy of Sciences USA 102:7766-7771.

Ballvora, A., Ercolano, M. R., Weiss, J., Meksem, K., Bormann, C. A., Oberhagemann, P., Salamini, F. and Gebhardt, C. (2002). The Rl gene for potato resistance to late blight (Phytophthora infestans) belongs to the leucine zipper/NBS/LRR class of plant resistance genes. Plant J. 30:361-371.

Bhattacharjee, S., Hiller, N. L., Liolios, K., Win, J., Kanneganti, T. D., Young, C., Kamoun, S. and Haldar, K. (2006). The malarial host-targeting signal is conserved in the Irish potato famine pathogen. PLoS Pathog. 2:e50

Birch, P. R., Armstrong, M., Bos, J., Boevink, P., Gilroy, E. M., Taylor, R. M., Wawra. S., Pritchard, L., Conti, L., Ewan, R., Whisson, S. C., van West, P., Sadanandom, A. and Kamoun, S. (2009). Towards understanding the virulence functions of RXLR effectors of the oomycete plant pathogen Phytophthora infestans. J. Exp. Bot. 60:1133-1140.

Birch, P. R., Boevink, P. C., Gilroy, E. M., Hein, I., Pritchard, L., and Whisson, S. C. (2008). Oomycete RXLR effectors: Delivery, functional redundancy and durable disease resistance. Curr. Opin. Plant Biol. 11:373-379.

Birch, P. R., Rehmany, A. P., Pritchard, L., Kamoun, S. and Beynon, J. L. (2006). Trafficking arms: Oomycete effectors enter host plant cells. Trends Microbiol. 14:8-11. 
Boner, C. (2003). The Bcl-2 pretein family: sensors and checkpoints for life-or-death decisions. Mol. Immunol. 30:615-647.

Bos, J. I., Kanneganti, T. D., Young, C., Cakir, C., Huitema, E., Win, J., Armstrong, M. R., Birch, P. R. and Kamoun, S. (2006). The C-terminal half of Phytophthora infestans RXLR effector AVR3a is sufficient to trigger R3a-mediated hypersensitivity and suppress INF1-induced cell death in Nicotiana benthamiana. Plant J. 48:165-176.

Bos, J. I. B., Chaparro-Garcia, A., Quesada-Ocampo, L. M., McSpadden-Gardener, B. B. and Kamoun, S. (2009). Distinct amino acids of the Phytophthora infestans effector AVR3a condition activation of R3a hypersensitivity and suppression of cell death. Mol. Plant Microbe Interact. 22:269-281.

Dangl, J. L. and Jones, J. D. (2001). Plant pathogens and integrated defence responses to infection. Nature. 411:826-833.

Dou, D., Kale, S. D., Wang, X., Chen, Y., Wang, Q., Jiang, R. H., Arredondo, F. D., Anderson, R. G., Thakur, P. B., McDowell, J. M., Wang, Y. and Tyler, B. M. (2008a). Conserved C-terminal motifs required for avirulence and suppression of cell death by Phytophthora sojae effector Avr1b. Plant Cell 20:1118-1133.

Dou, D., Kale, S. D., Wang, X., Jiang, R. H., Bruce, N. A., Arredondo, F. D., Zhang, X. and Tyler, B. M. (2008b). RXLRmediated entry of Phytophthora sojae effector Avrlb into soybean cells does not require pathogen-encoded machinery. Plant Cell 20:1930-1947.

Erwin, D. C. and Ribeiro, O. K. (1996). Phytophthora Diseases Worldwide, The American Phytopathological Society, St Paul, MN.

Fry, W. E. (2008). Phytophthora infestans: The plant (and $R$ gene) destroyer. Mol. Plant Pathol. 9:385-402.

Govers, F. and Bouwmeester, K. (2008). Effector trafficking: RXLR-dEER as extra gear for delivery into plant cell. Plant Cell 20:1728-1730.

Grouffaud, S., van West, P., Avrova, A. O., Birch, P. R. and Whisson, S. C. (2008). Plasmodium falciparum and Hyaloperonospora parasitica effector translocation motifs are functional in Phytophthora infestans. Microbiology 154:3743-3751.

Haas, B. and Kamoun, S. et al. (2009). Genome sequence and comparative analysis of the Irish potato famine pathogen Phytophthora infestans. Nature 461:393-398.

Hausbeck, M. K. and Lamour, K. H. (2004). Phytophthora capsici on vegetable crops: research progress and management challenges. Plant Dis. 88:1292-1303.

Hewitt, W. B. and Pearson, R. C. (1988). Downy mildew. In Compendium of Grape Diseases, ed, RC Pearson, AC Goheen, pp. 11-13. St. Paul, MN: APS Press.

Huang, S., van der Vossen, E., Kuang, H., Vleeshouwers, V., Zhang, N., Borm, T., van Eck, H., Baker, B., Jacobsen, E. and Visser, R. (2005). Comparative genomics enabled the isolation of the $R 3 a$ late blight resistance gene in potato. Plant $J .42$ : 251-261.

Jamir, Y., Guo, M., Oh, H. S., Petnicki-Ocwieja, T., Chen, S., Tang, X. et al. (2004). Identification of Pseudomonas syringae type III effectors that can suppress programmed cell death in plants and yeast. Plant J. 37:554-565.
Jiang, R. H., Tripathy, S., Govers, F. and Tyler, B. M. (2008). RXLR effector reservoir in two Phytophthora species is dominated by a single rapidly evolving superfamily with more than 700 members. Pro. Nat. Sci. USA 105:4874-4879.

Jones, J. D. and Dangl, J. L. (2006). The plant immune system. Nature 444:323-329.

Judelson, H. S. and Blanco, F. A. (2005). The spores of Phytophthora: weapons of the plant destroyer. Nat. Rev. Microbiol. 3:47-58

Kamoun, S. (2006). A catalogue of the effector secretome of plant pathogenic oomycetes. Annu. Rev. Phytopathol. 44:41-60.

Kamoun, S. (2007). Groovy times: Filamentous pathogen effectors revealed. Curr. Opin. Plant Biol. 10:358-365.

Kamoun, S. and Smart, C. D. (2005). Late blight of potato and tomato in the genomics era. Plant Dis. 89:692-699.

Kamoun, S., van West, P., Vleeshouwers, V. G. A. A., de Groot, K. E. and Goers, F. (1998). Resistance of Nicotiana benthamiana to Phytophthora infestans in mediated by the recognition of the elicitor protein INF1. Plant Cell 10:1413-1426.

Kamoun, S., Young, M., Glascock, C. and Tyler, B. M. (1993). Extracellular protein elicitors from Phytophthora: Host-specificity and induction of resistance to fungal and bacterial phytopathogens. Mol. Plant Microbe Interact. 6:15-25.

Lamour, K. H. and Kamoun, S. (2009). Oomycete Genetics and Genomics: Diversity, Intreractions and Research Tools. Hoboken, NJ: Wiley-Blackwell.

Lokossou, A. A., Park, T. H., van Arkel, G., Arens, M., RuyterSpira, C., Morales, J., Whisson, S. C., Birch, P. R., Visser, R. G, Jacobsen, E. and van der Vossen, E. A. (2009). Exploiting Knowledge of $R / A v r$ Genes to Rapidly Clone a New LZ-NBSLRR Family of Late Blight Resistance Genes from Potato Linkage Group IV. Mol. Plant Microbe Interact. 22:630-641.

Morgan, W. and Kamoun, S. (2007). RXLR effectors of plant pathogenic oomycetes. Curr. Opin. Microbiol. 10:332-338.

Nürnberger, T., Brunner, F., Kemmerling, B. and Piater, L. (2004). Innate immunity in plants and animals: striking similarities and obvious differences. Immunol Rev. 198:249-66.

O'Connell, R. J. and Panstruga, R. (2006). Tete a tete inside a plant cell: establishing compatibility between plants and biotrophic fungi and Oomycetes. New Phytol. 171:699-718.

Oh, S.-K., Young, C., Lee, M., Oliva, R., Bozkurt, T. O., Cano, L. M., Win, J., Bos, J. I., Liu, H. Y., van Damme, M., Morgan, W., Choi, D., Van der Vossen, E. A., Vleeshouwers, V. G and Kamoun, S. (2009). In planta expression screens of Phytophthora infestans RXLR effectors reveal diverse phenotypes, including activation of the Solanum bulbocastanum disease resistance protein Rpi-blb2. Plant Cell 21:2928-2947.

Panstruga, R. (2003). Establishing compatibility between plants and obligate biotrophic pathogens. Curr. Opin. Plant Biol. 6: 320-326.

Qutob, D., Tedman-Jones, J., Dong, S., Kuflu, K., Pham, H., Wang, Y., Dou, D., Kale, S. D., Arredondo, F. D., Tyler, B. M. and Gijzen, M. (2009). Copy number variation and transcriptional polymorphisms of Phytophthora sojae RXLR effector genes Avr1a and Avr3a. PLoS One 4:e5056.

Rehmany, A. P., Gordon, A., Rose, L. E., Allen, R. L., Armstrong, 
M. R., Whisson, S. C., Kamoun, S., Tyler, B. M., Birch, P. R. and Beynon, J. L. (2005). Differential recognition of highly divergent downy mildew avirulence gene alleles by $R P P 1$ resistance genes from two Arabidopsis lines. Plant Cell 17: 1839-1850.

Rizzo, D. M., Garbelootto, M. and Hansen, E. M. (2005). Phytophthora ramorum: integrative research and management of an emerging pathogen in California and Oregon forests. Anпи. Rev. Phytopathol. 43:309-335.

Schmitthenner, A. F. (1985). Problems and progress toward control of Phytophthora root rot of soybean. Plant Dis. 69:362368.

Schornack, S., Huitema, E., Cano, L. M., Bozkurt T. O., Oliva, R., Van Damme, M., Schwizer, S., Raffaele, S., Chaparro-Garcia, A., Farrer, R., Segretin, M. E., Bos, J., Haas, B. J., Zody, M. C., Nusbaum, C., Win, J., Thines, M. and Kamoun, S. (2009). Ten things to know about oomycete effectors. New Phytol. 10:795-803.

Shan, W., Cao, M., Leung, D. and Tyler, B. M. (2004). The Avrlb locus of Phytophthora sojae encodes an elicitor and a regulator required for avirulence on soybean plants carrying resistance gene Rps1b. Molecular Plant-Microbe Interactions 17:394-403.

Slusarenko, A. J. and Schlaich, N. L. (2003). Downy mildew of Arabidopsis thaliana caused by Hyaloperonospora parasitica (formerly Peronospora parasitica). Mol. Plant Pathol. 4:159170.

Sohn, K. H., Lei, R., Nemri., and Jones, J. D. (2007). The downy mildew effector proteins ATR1 and ATR13 promote disease susceptibility in Arabidopsis thaliana. The Plant Cell 19: 4077-4090.

Song, J., Bradeen, J. M., Naess, S. K., Raasch, J. A., Wielgus, S. M., Haberlach, G. T., Liu, J., Kuang, H., Austin-Phillips, S., Buell, C. R., Helgeson, J. P. and Jiang, J. (2003). Gene RB cloned from Solanum bulbocastanum confers broad spectrum resistance to potato late blight. Proc. Natl. Acad. Sci. USA 100:
9128-9133.

Tyler et al. (2006). Phytophthora genome sequences uncover evolutionary origins and mechanisms of pathogenesis. Science 313:1261-1266.

Tyler, B. M. (2009). Entering and breaking: virulence effector proteins of oomycete plant pathogens. Cell Microbebiol. 11:13-20.

van der Vossen, E. A. G, Gros, J., Sikkema, A., Muskens, M., Wouters, D., Wolters, P., Pereira, A. and Allefs, S. (2005). The Rpi-blb2 gene from Solanum bulbocastanum is an Mi-1 gene homologh conferring broad-spectrum late blight resistance in potato. Plant J. 44:208-222.

van Poppel, P. M., Guo, J., van de Vondervoort, P. J., Jung, M. W., Birch, P. R., Whisson, S. C. and Govers, F. (2008). The Phytophthora infestans avirulence gene Avr4 encodes an RXLRdEER effector. Mol. Plant Microbe Interact. 21:1460-1470.

van Poppel, P. M., Jiang, R. H., Sliwka, J. and Govers, F. (2009). Recognition of Phytophthora infestans Avr4 by potato R4 is triggered by C-terminal domains comprising W motifs. Mol. Plant Pathol. 10:611-620.

Vleeshouwers, V. G., Rietman, H. and Krenek, P. et al. (2008). Effector genomics accelerates discovery and functional profiling of potato disease resistance and Phytophthora infestans avirulence genes. PLoS One 3:e2875.

Vleeshouwers, V. G. A. A., Driesprong, J.-D., Kamphuis, L. G, Torto-Alalibo, T., van't Slot, K. A. E., Govers, F., Visser, R. G. F., Jacobsen, E. and Kamoun, S. (2006). Agroinfection-based high throughput screening reveals specific recognition of INF elicitins in Solanum. Mol. Plant Pathol. 7:499-510.

Whisson, S. C. et al. (2007). A translocation signal for delivery of oomycete effector proteins into host plant cells. Nature 450: 115-118.

Win, J., Kanneganti, T. D., Torto-Alalibo, T. and Kamoun, S. (2006). Computational and comparative analyses of 150 fulllength cDNA sequences from the oomycete plant pathogen Phytophthora infestans. Fungal Genet. Biol. 43:20-33. 